\title{
Occurrence in coastal waters and endogenous tidal swimming rhythms of late megalopae of the shore crab Carcinus maenas: implications for onshore recruitment
}

\author{
Chaoshu Zeng*, Ernest Naylor \\ School of Ocean Sciences, University of Wales-Bangor, Menai Bridge, Gwynedd LL59 5EY, United Kingdom
}

\begin{abstract}
Previous studies have shown that newly released zoea larvae of the shore crab Carcinus maenas (L.) exhibut ebb-phased tidal vertical migration rhythms of upward swimming associated with transport offshore in ebb tidal flows. This gives rise to the question as to how later larvae of the species return to the intertidal zone. Repeated surface plankton sampling in coastal waters revealed that megalopae, the last larval stage of the crab, swarmed in surface waters mainly during flood tides and particularly at night. It is likely that flood-phased upward swimming ensures onshore transport of the larvae. Employing an infra-red actography system, endogenous circatidal rhythms of swimming activity were detected in constant laboratory conditions in freshly collected megalopae from inshore waters. However, in such conditions, upward swimming occurred at the times of expected ebb, not flood. It is proposed that inshore flood transport of megalopae is driven primarily by exogenous factors, which result in swarming of pre-moult megalopae towards the upper intertidal zone where settlement of first stage juvenile crabs occurs. It is suggested that the ebb-phased endogenous circatidal rhythm of upward swimming is adaptive in reducing the risk of premature stranding of megalopae, permitting them to oscillate between the intertidal and near shore waters until moulting is imminent and a suitable sub. stratum is encountered. Of megalopae collected in inshore coastal waters, and maintained in the laboratory at water temperatures close to those of the field, nearly $60 \%$ moulted in $2 \mathrm{~d}, 95 \%$ in $4 \mathrm{~d}$ and $100 \%$ in $7 \mathrm{~d}$ after collection. Since the average development time for $C$. maenas megalopae is reported to be $13 \mathrm{~d}$, the data provide evidence that only late megalopae return to coastal areas.
\end{abstract}

KEY WORDS: Carcinus maenas - Megalopae-Metamorphosis Flood tide transport Circatidal swımming rhythms

\section{INTRODUCTION}

Many estuarine and coastal benthic invertebrates are known to release or disperse their planktonic larvae away from aduit habitats (Strathmann 1982, Scheltema 1986, Boicourt 1987, Epifanio 1988a, b, Rothlisberg 1988), from which it follows that mechanisms of recruitment of later larvae or juveniles must occur. Recruitment by passive transport has been proposed (de Wolf 1974, Boicourt 1982, Stancyk \& Feller 1986), but increasing evidence, particularly in decanod crus-

•E-mail: osp043@sos.bangor.ac.uk taceans, suggests that active behavioural participation of larvae occurs in the transport process (Rothlisberg 1982, 1988, Epifanio 1988a, b, McConaugha 1988. Rothlisberg et al. 1995). Typically, this has been observed to occur through ontogenetic changes of vertical distribution or complex rhythmic migrations which affect trajectories of transport in an environment of vertical current shear (Epifanio 1988a, b, McConaugha 1988, Rothlisberg 1988). For invertebrate larvae of limited swimming ability, such behaviour offers some control over the destination of horizontal transport.

In this context, recruitment into estuaries is better understood (Epifanio 1988a, b, McConaugha 1988). In the environment of net seaward water flows, a mecha- 
nism of 'selective tidal-stream transport', by which animals ascend in the water column on rising tides and descend to near bottom weak currents or on the bottom during falling tides, has been proposed for various animals, including fishes and their larvae (Harden Jones et al. 1978, Boehlert \& Mundy 1988, Wippelhauser \& McCleave 1988), as the mechanism of upstream transport. In invertebrate larvae, a similar behavioral mechanism is well documented in estuarine crab megalopae, which normally rise during nocturnal flood tides (Epifanio et al. 1984, Brookins \& Epifanio 1985, Mense \& Wenner 1989, Dittel \& Epifanio 1990, Little \& Epifanio 1991, De Vries et al. 1994, Olmi 1994, Queiroga et al. 1994). However, most of these observations were based on field surveys and the underlying behavioral control mechanisms remain unclear. Recently, following field observations of De Vries et al. (1994) that megalopae of the blue crab Callinectes sapidus and the tiddler crab Uca spp. peaked in abundance in an estuary at nocturnal flood tides, Tankersley \& Forward (1994) studied swimming behaviour of these larvae in laboratory constant conditions. The results showed that megalopae of Uca spp. displayed endogenous circatidal swimming rhythms, but the phase of maximum swimming was not identical to that recorded in the field. In megalopae of $C$. sapidus, a circadian rather than a circatidal rhythm was exhibited. It was concluded that the circatidal swimming rhythm is the behavioural basis of flood-tide transport of the fiddler crab larvae but that for the blue crab, flood-tide upward swimming is probably driven by behavioural responses to exogenous cues.

Compared to estuaries, the recruitment processes in coastal waters are poorly understood, yet even for estuarine invertebrate larvae dispersed offshore, acrossshelf transport to the vicinity of the estuarine mouth must be accomplished before re-invasion can occur (Boicourt 1987, Epifanio 1988b, Rothlisberg et al. 1995). Some species may depend on orientated swimming (Philips 1981, Cobb et al. 1989), but for most invertebrate larvae, this appears unlikely because of their limited swimming ability. Other proposed mechanisms include transport in wind-driven water movements (Johnson 1985, Johnson et al. 1986, Hobbs et al. 1992), by shoreward transport of surface slicks over tidally forced internal waves (Shanks 1983, 1985, 1988), by diel vertical migration-induced transport (Rothlisberg 1982, 1988) and by utilization of net landward near bottom flows (Epifanio 1988b, McConaugha 1988). However, although it has been reported in fishes (Arnold \& Cook 1984, Rijnsdorp et al. 1985, Metcalfe et al. 1994, Castongnag \& Gilbert 1995), so far no consideration appears to have been given to the possibility of selective tidal stream transport of invertebrate larvae in coastal waters. In many parts of continental shelf, currents are dominated by the oscillatory motion of tides. There, efficient unidirectional transport could be induced by rhythmic vertical migrations that are phase-locked with tidal currents which are generally sheared in the vertical, with flow weaker close to the seabed because of friction (Hill 1991a, b, 1995).

In the shore crab Carcinus maenas (L.), widely found on coasts and estuaries of northwestern Europe and northeastern America (Crothers 1968, Berril 1982), our previous studies have revealed that newly released zoea larvae exhibited tidal vertical migration rhythms of ascent during ebb tides in coastal waters which should lead to transport offshore in ebbing tidal flows (Zeng \& Naylor 1996). A field investigation in a Portuguese estuary has also demonstrated that newly hatched C. maenas larvae were flushed seaward and that the megalopa was the stage of reinvasion (Queiroga et al. 1994). These observations raise the question as to how recruitment of $C$. maenas megalopae occurs on coasts. Field and laboratory studies were designed in the present study to investigate this question.

\section{MATERIALS AND METHODS}

Field sampling. Repeated surface plankton samples were taken at 2 sites in the Menai Strait, North Wales, during June-August, 1994. Site 1 is located at Menai Bridge $\left(53^{\circ} 13^{\prime} \mathrm{N}, 04^{\circ} 09^{\prime} \mathrm{W}\right)$ in the middle reaches of

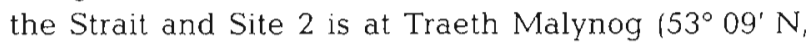
$04^{\circ} 19^{\prime} \mathrm{W}$ ), near the southwestern end of the Strait where high tides occur nearly 1 h earlier than at Site 1. The tides in the Strait are typically semidiurnal with a period of approximately $12.4 \mathrm{~h}$ and, at the sampling sites, slack water occurs about the time of high tide (Sherwin 1992; Admiralty Tide Tables 1994).

Samples were taken, using a small boat, by towing a surface plankton net of $50 \mathrm{~cm}$ diameter and $0.3 \mathrm{~mm}$ mesh size at a constant speed (approx. 2.5 knots) for $10 \mathrm{~min}$, at a depth of no more than $1 \mathrm{~m}$, at different stages of the tide. Sampling was normally conducted over a tidal cycle and the sampling intervals were generally no more than $2 \mathrm{~h}$. At Site 1 , a 24 h continuous hourly sampling programme was carried out

Plankton samples were fixed in $4 \%$ formalin immediately upon collection. Following the descriptions of Rice \& Ingle (1975), entire samples were searched for megalopae of Carcinus maenas and numbers counted in the laboratory.

Laboratory studies of megalopa tidal swimming rhythms. The fjeld surveys revealed that Carcinus maenas megalopae aggregated in surface waters mainly at a late phase of nocturnal flood tides, normally within 2 h of high tide. Accordingly, the mega- 
lopae for laboratory experiments were collected at such times either by manually towing the plankton net described above along the Menai Bridge pier or by towing from an engine-powered boat. To minimize possible damage to the larvae, the duration of each tow was limited to no more than $10 \mathrm{~min}$. Samples were immediately transferred to the laboratory and the megalopae separated out and identified.

After sorting, larvae in batches of several hundreds (see figure legends) were placed in an actograph similar to that described by Hough \& Naylor (1992b). This consisted of a chamber containing seawater and 2 sets of 4 infra-red transmitters and receivers in an array on each side of the chamber. The chamber was constructed of $6 \mathrm{~mm}$ transparent Perspex with interior dimensions of $40 \mathrm{~cm}$ high, $15 \mathrm{~cm}$ wide and $5 \mathrm{~cm}$ from front to back. Two sets of 4 infra-red transmitters and receivers, operating from front to back across the narrowest dimension of the chamber, were arranged so that one set of the transmitters and receivers was placed just below the water surface and the other just above the bottom. During the experiments, an event was recorded each time an infra-red light beam was interrupted by larvae swimming across it. All light channels were monitored by a BBC model B microcomputer and, every $15 \mathrm{~min}$, the cumulative sum of beam interruptions in each channel was loaded to a cassette recorder. A header-tank with a tiny pipe of $1.0 \mathrm{~mm}$ diameter inner bore provided very slow clean seawater supply (approx. $150 \mathrm{ml} \mathrm{h}^{-1}$ ) into one end of the chamber. An outflow pipe was placed at the other end, protected by a mesh panel of $0.3 \mathrm{~mm}$ aperture to prevent outflow of the larvae.

No more than $8 \mathrm{~h}$ elapsed between the collections and the start of an experiment. All experiments were carried out in constant darkness, allowing a 1 to $2 \mathrm{~h}$ acclimation period before recording began. Once an experiment started, the whole system was left undisturbed and larvae were not fed during the experiments. At the end of a trial, the numbers of surviving megalopae and newly moulted crabs were counted. During all experiments, water temperature was maintained at $16 \pm 1^{\circ} \mathrm{C}$ and salinity varied between 32 and $34 \%$. Mean field seawater temperature and salinity normally varied between 13 and $18^{\circ} \mathrm{C}$ and between 31 and $34 \%$ respectively during the period of the experiments.

Records of the 4 channels in the top and bottom block of sensors were summed and plotted as 'swimming activity in top channels' and 'swimming activity in bottom channels' against elapsed time respectively. Data plots are of raw data and of periodogram analysis performed as descrihed hy Williams \& Naylor (1978)

Time to moult of the megalopae. Proximity to moulting of freshly collected megalopae from inshore coastal waters was determined by recording the time to meta- morphosis of several hundred of such larvae taken in tow nets. The larvae were collected at Sites 1 or 2 during July-August 1994. Collecting and sorting procedures were the same as for the swimming rhythm experiments described above. Megalopae were evenly allocated into several tanks, each containing $2.5 \mathrm{l}$ of fresh seawater with Artemia nauplii added at random intervals as food. Some experiments were conducted under constant light and others in natural light/dark cycles, in water temperature of $16.5 \pm 0.5^{\circ} \mathrm{C}$ (in natural light/dark cycles) or $18 \pm 1^{\circ} \mathrm{C}$ (in constant light) and salinity of $32 \pm 1 \%$.

Since metamorphosis of megalopae of Carcinus maenas is known to occur with circatidal rhythmicity at the expected times of high tides (Zeng et al. in press), the tanks were checked for newly metamorphosed first stage crabs at times of expected low water every $24 \mathrm{~h}$. On each occasion, all exuviae, newly moulted crabs and dead megalopae were removed.

\section{RESULTS}

\section{Megalopa abundance in coastal surface waters}

Figs. 1A-E show abundance of megalopae of Carcinus maenas in surface plankton tows over tidal cycles of different phasing at Sites 1 and 2 during JuneAugust 1994. The results demonstrate that in general, the megalopae were most abundant near the surface during the later stage of flood tides. This occurred over tidal cycles sampled during the night (Fig. 1C-E) and also during the morning at times when both of the local semilunar flood tides happen to occur during daylight on long summer days (Fig. 1A, B). However, in 1 series of samples obtained over 2 tidal cycles, megalopa abundance was much greater during the nocturnal flood tide than during the daytime one (Fig. 1E), indicative of diel periodicity imposed upon the tidal pattern. This tide-related pattern of megalopa abundance at the surface is summarized in Fig. 2, a pooled data plot, normalized around the times of high water.

\section{Endogenous tidal swimming rhythms in megalopae}

Circatidal thythms of swimming activity were apparent in all experiments using freshly collected megalopae of Carcinus maenas kept in constant laboratory conditions. Peaks of swimming activity recurred at approximately $12.4 \mathrm{~h}$ intervals in records of both top and bottom sets of recording channels in any one trial (Figs. 3A, 4A \& 5A show examples) and periodogram analysis confirmed that the rhythms in all experiments were circatidal (Figs. 3B, 4B \& 5B). In all experiments, 

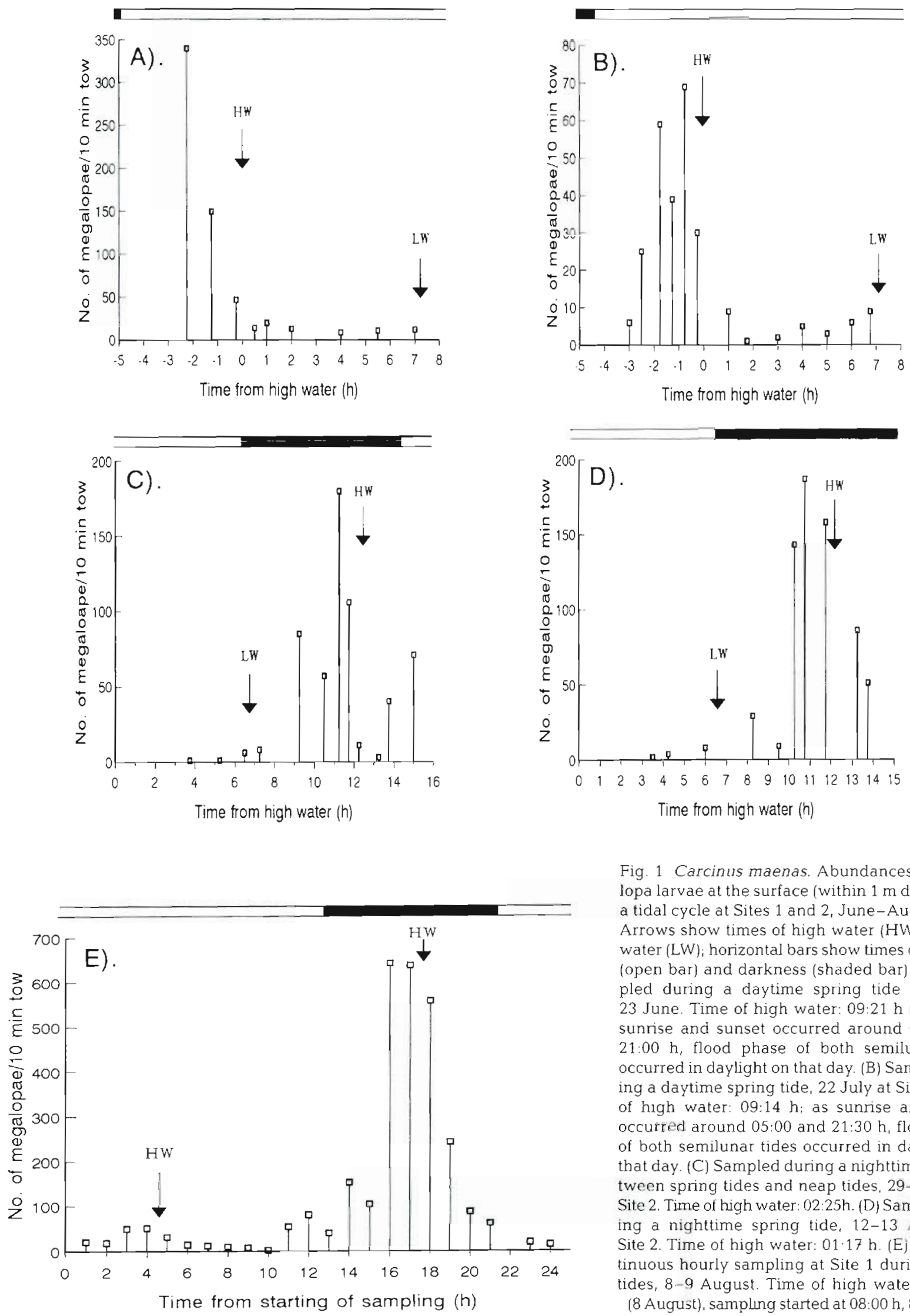

Fig. 1 Carcinus maenas. Abundances of megalopa larvae at the surface (within $1 \mathrm{~m}$ depth) over a tidal cycle at Sites 1 and 2, June-August 1994. Arrows show times of high water (HW) and low water (LW); horizontal bars show times of daylight (open bar) and darkness (shaded bar). (A) Sampled during a daytime spring tide at Site 2 , 23 June. Time of high water: 09:21 h (GMT); as sunrise and sunset occurred around 04:30 and 21:00 h, flood phase of both semilunar tides occurred in daylight on that day. (B) Sampled during a daytime spring tide, 22 July at Site 2 . Time of high water: 09:14 h; as sunrise and sunset occurred around 05:00 and 21:30 h, flood phase of both semilunar tides occurred in daylight on that day. (C) Sampled during a nighttime tide between spring tides and neap tides, 29-30 July at Site 2. Time of high water: 02:25h. (D) Sampled during a nighttime spring tide, 12-13 August at Site 2. Time of high water: $01 \cdot 17 \mathrm{~h}$. (E) $24 \mathrm{~h}$ continuous hourly sampling at Site 1 during spring tides, $8-9$ August. Time of high water: $11: 30 \mathrm{~h}$ (8 August), samplung started at $08: 00 \mathrm{~h}, 8$ August 


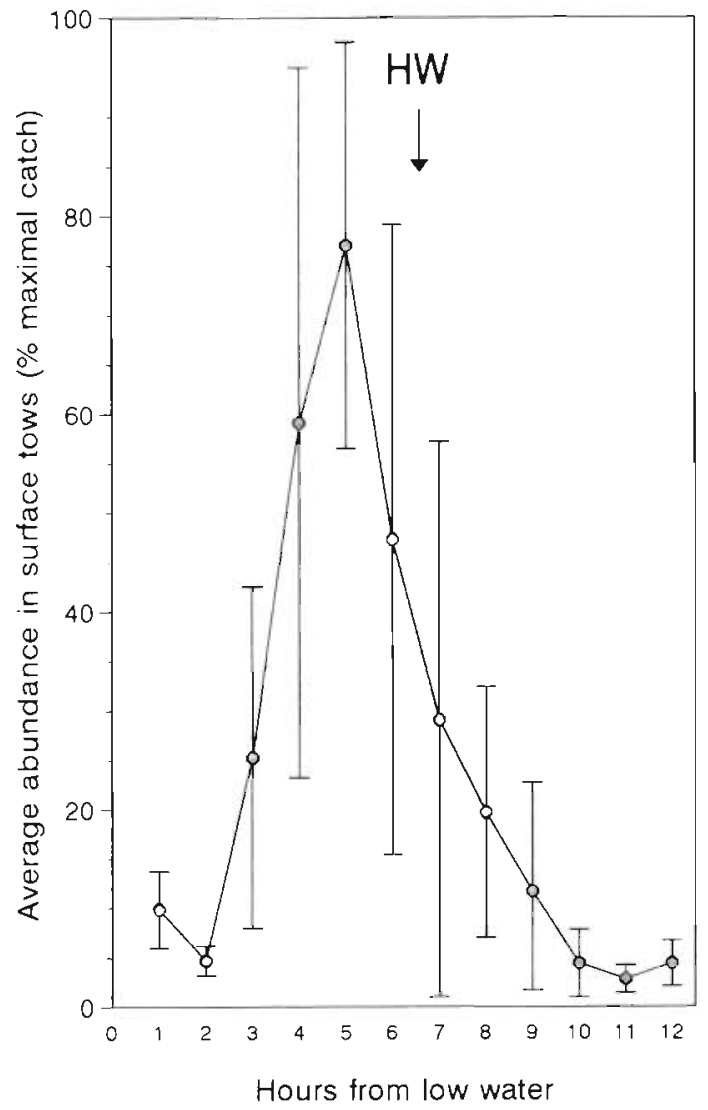

Fig. 2. Carcinus maenas. Average abundance of megalopa larvae near the surface (within $1 \mathrm{~m}$ ) in relation to the tidal cycle. Error bars indicate \pm SD. HW: high water. All data from Fig. 1 were pooled regardless of time and date of the collection and spring/neap cycle. Because of variations in absolute numbers of larvae caught in different samples, all data have been transformed to relative values by dividing by the maximum abundance recorded during respective sampling periods before pooling. Samples were rounded up to the nearest hour

peaks and troughs in surface and bottom records coincided in phase and both records were near zero during inactive phases, suggesting that larvae were settled on the floor of the test chamber when not swimming upwards. In all cases, peak swimming occurred just after the expected time of high tide, with upward swimming beginning at or before expected high tide in the early peaks of records (Figs. 3A-5A). There was no evidence of circadian modulation of the circatidal rhythm in the raw data of any trial. Experiments were usually terminated after 5 or 6 tidal cycles, by which time normally more than half of the megalopae had metamorphosed to the first crab stage (see below).

Tiñe to moult of the megalopae from coastal waters. Monitoring the time to metamorphosis of freshly collected megalopae from inshore water revealed that all of them were at a late stage in the moulting cycle. Observations were made on 5 batches of megalopae collected during July and August 1994 from Sites 1 and 2 at temperatures close to those of field. Pooled data for nearly 2000 larvae in these 5 batches monitored in the laboratory show that moulting peaked on the second day after collection and on average, nearly $60 \%$ metamorphosed in $2 d, 97 \%$ in $4 \mathrm{~d}$ and $100 \%$ in $7 \mathrm{~d}$ after collection (Fig. 6). Overall survival rates to the first crab stage were generally more than $90 \%$ in these experiments.

\section{DISCUSSION}

Present field samples demonstrate that megalopa larvae of the shore crab Carcinus maenas occur most abundantly in near-shore surface waters during the flood tide period. One set of samples during 2 successive high tides showed that the nocturnal flood tide catches were much greater than the daytime ones, confirming preliminary observations used to establish optimal timing for the collection of large numbers of megalopae for the laboratory experiments. However, daytime catches can also be high if the flood phase of both semilunar tides occurred during daylight on long summer days (Fig. 1A, B). Such megalopae, freshly collected from near-shore waters, were clearly mostly within 2 or $3 \mathrm{~d}$ of metamorphosis to the first crab stage irrespective of the time during the recruitment season (Fig. 6). So, since the normal development time for $C$. maenas megalopae is reported to be $13 \mathrm{~d}$ at a temperature $\left(18^{\circ} \mathrm{C}\right)$ (Dawirs 1985$)$ close to or higher than those at which present observations were made, it is evident that megalopae of $C$. maenas in nearshore coastal waters were not developing locally but were recruited from offshore. The arrival in the near-shore zone of megalopae about to metamorphose to the first crab stage is clearly ordered in space and time, consistent with the knowledge that small $C$. maenas up to $35 \mathrm{~mm}$ carapace width are particularly abundant in the high intertidal on rocky shores (Hunter \& Naylor 1993, Warman et al. 1993). Moreover, we have additional unpublished field data which show that the first stage crabs of carapace width around $2 \mathrm{~mm}$ occurred most abundantly, at densities of up to several hundred $\mathrm{m}^{-2}$, at the level of high water neap tides in the study area. Hence, since newly released $C$. maenas zoeae appear to utilize tidal vertical migration rhythms to exploit tidal ebb currents for dispersal (Zeng \& Naylor 1996), it is appropriate to consider whether late megalopae exploit flood tide currents on their return to the intertidal zone. Tho prosont ficld results suggest that this may be so. No doubt, as coastal tidal currents normally have both cross-shelf and along-shore components, the tidal vertical migration rhythms will also lead to advection of 


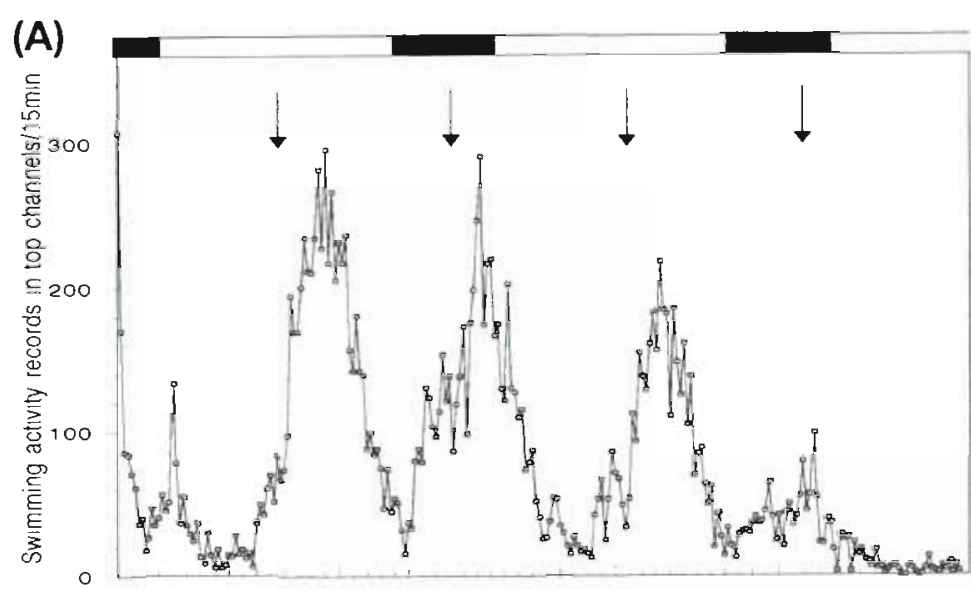

Fig. 3. Carcinus maenas. (A) Swimming activity records of field-caught megalopa larvae showing tidal rhythms of swimming in constant laboratory conditions. Upper and lower parts of graph represent record at surface and bottom layer of a vertical chamber respectively. Arrows show times of expected high tides at collection site. Horizontal bar shows times of expected daylight (open bar) and darkness (shaded bar) in the field. Experiment started at 01:00 h (GMT), 11 July 1994, 2 h after collection and with an initial number of 430 freshly collected megalopa larvae. Larvae were collected by lowing a plankton net along the Menai Bridge pier during nocturnal flood tides. Totals of 134 megalopae and 176 first stage crabs survived when the experiment stopped. (B) Periodogram analysis of the data presented in (A). Upper and lower parts of the graph represent, as periodogram statistic. results of swimming activity records at top and bottom channels, respectively. $95 \%$ confidence limits are derived after randomization of original data

(B)
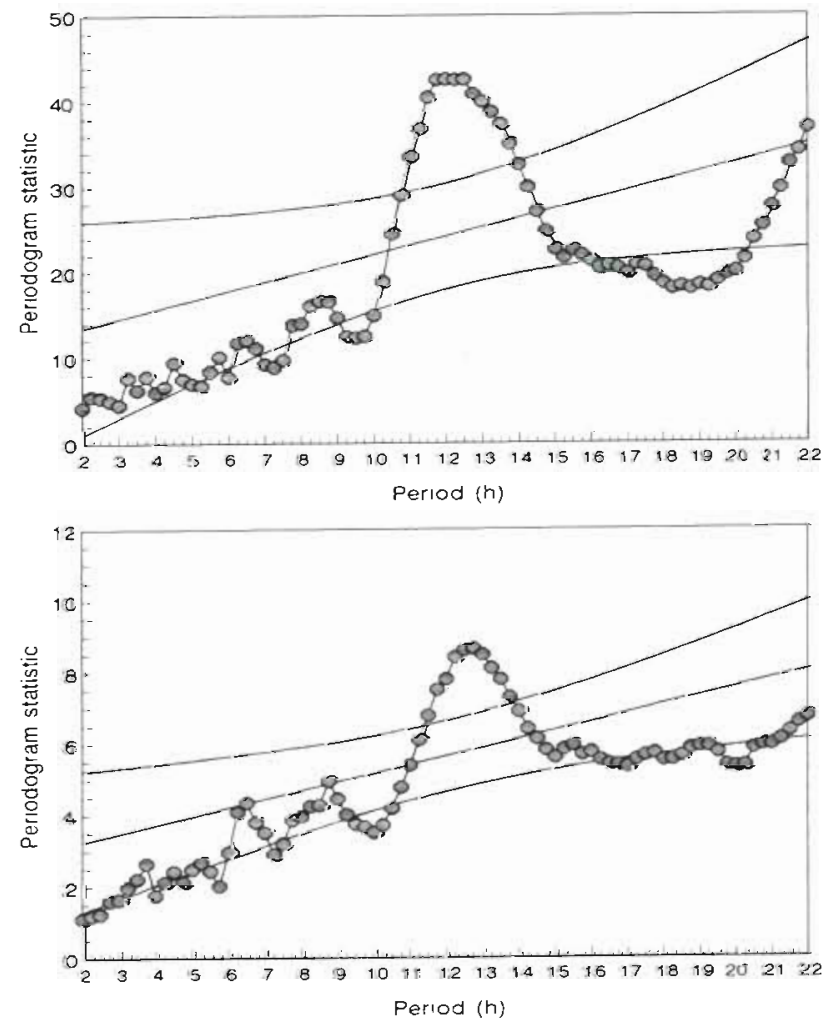

larvae along-shore. To some extent, the along-shore ebb transport of first zoea larvae (Zeng \& Naylor 1996) will be compensated for by along-shore flood transport of megalopae as reported here. In any case, along-shore transport may not be critical for this ubiquitous species on the coasts of northwestern Europe. However, further study of the effects of along-shore transport and of the occurrence and behaviour of intermediate zoea stages would be worthwhile.

In a Portuguese estuary, it has also been shown that newly released zoea larvae of Carcinus maenas are flushed seaward and that megalopae, the reinvasive stage, were abundant in the estuarine water column mainly during nocturnal flood tides (Queiroga et al. 1994). Clearly, flood-phased tidal upward swimming could account for the increased numbers of megalopae observed near the surface of inshore waters on late flood tides in the present study and serve as the mechanisms for both coastal and estuarine recruitment of this crab. However, though experimental evidence in the present study certainly demonstrates the occurrence of an endogenous circatidal rhythm of upward swimming in $C$. maenas megalopae, the phase of this in the labora- 

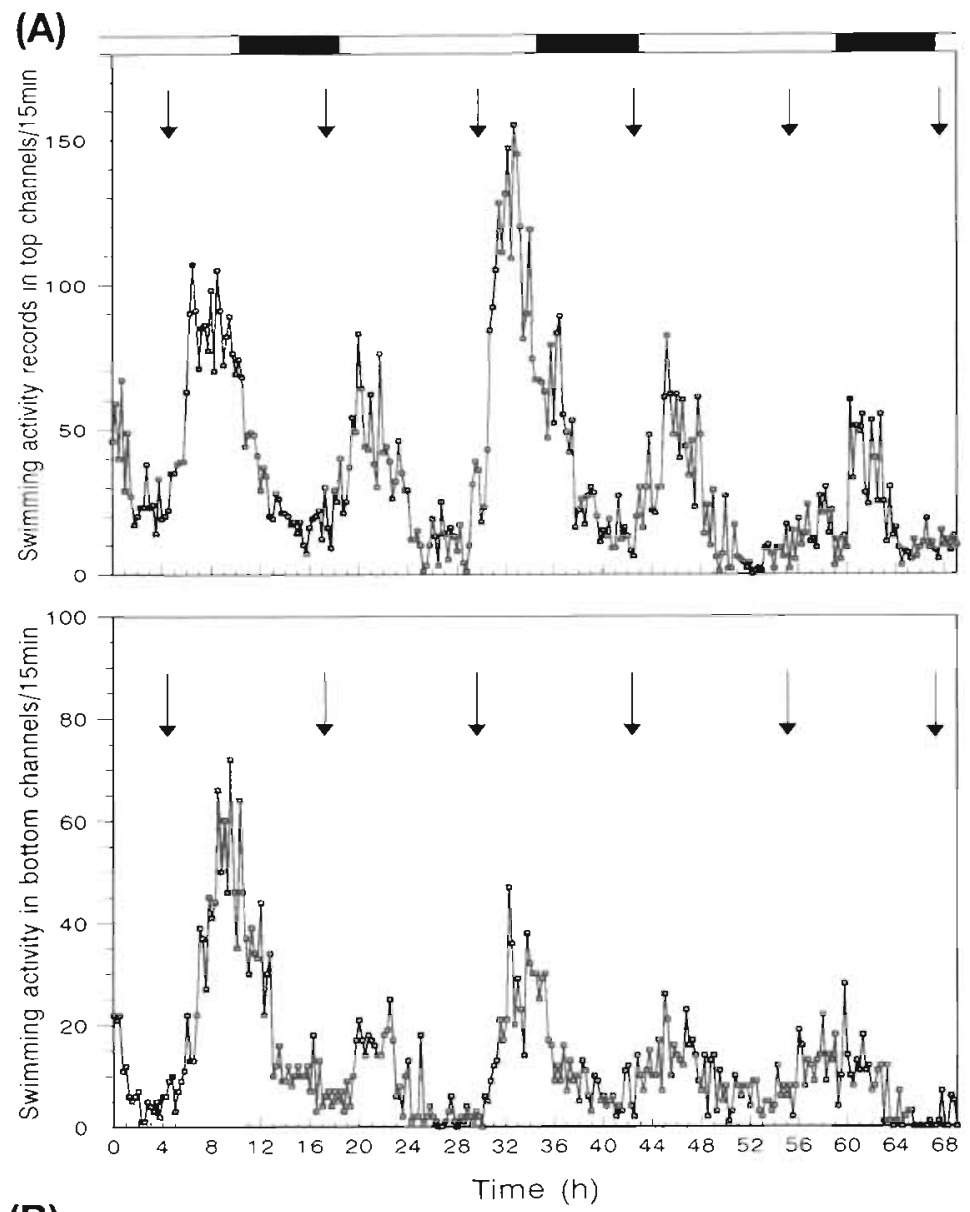

Fig. 4. Carcinus maenas. (A) Swimming activity records of field-caught megalopa larvae showing circatidal rhythms of swimming in constant laboratory conditions. Experiment started at 09:00 h, $30 \mathrm{July} 1994$ with an initial number of 250 freshly collected megalopa larvae, collected from Site 2 during flood tide after spring tides. Due to water fouling, only 63 megalopae and crabs survived when the experiment stopped, among which 19 were first crabs. (B) Periodogram analysis of the data presented in (A). Symbols and further details as in Fig. 3

(B)
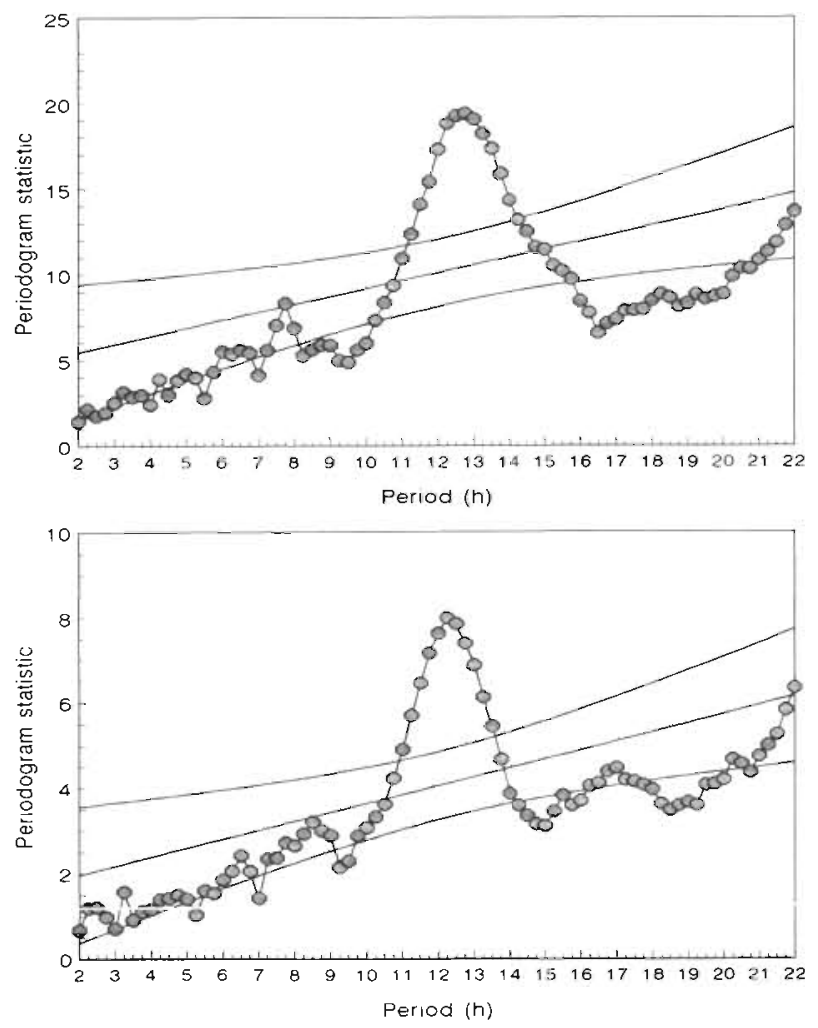

tory does not coincide with observed behaviour in the field. Moreover, though there is evidence of diel rhythmicity in the field-catch data, the laboratory-recorded rhythmicity appears mainly circatidal. Hence if the ebb phase of the laboratory-recorded rhythm reflects behaviour in the field, which is a reasonable assumption unless and until demonstrated otherwise, then it seems unlikely that the endogenous rhythm plays a significant part in onshore transport of $C$. maenas megalopae. Therefore, the most reasonable conclusion on present evidence is that flood-tide upward swimming by megalopae returning inshore is driven primarily by exogenous factors.

A feature of the tidal swimming rhythms of Carcinus maenas first stage zoeae recorded in the laboratory is that the peaks of the records were always reciprocal when comparing abundance at the top and bottom of the test chamber (Zeng \& Naylor 1996, in press a, b). In contrast, in late megalopae, peaks were identically phased and the records were always near zero in both top and bottom channels during the inactive phase. This sugqests that whilst zoea larvae were rhythmically moving up and down in the water column while remaining planktonic, late megalopae settled on the bottom during their inactive phase and only dispersed 

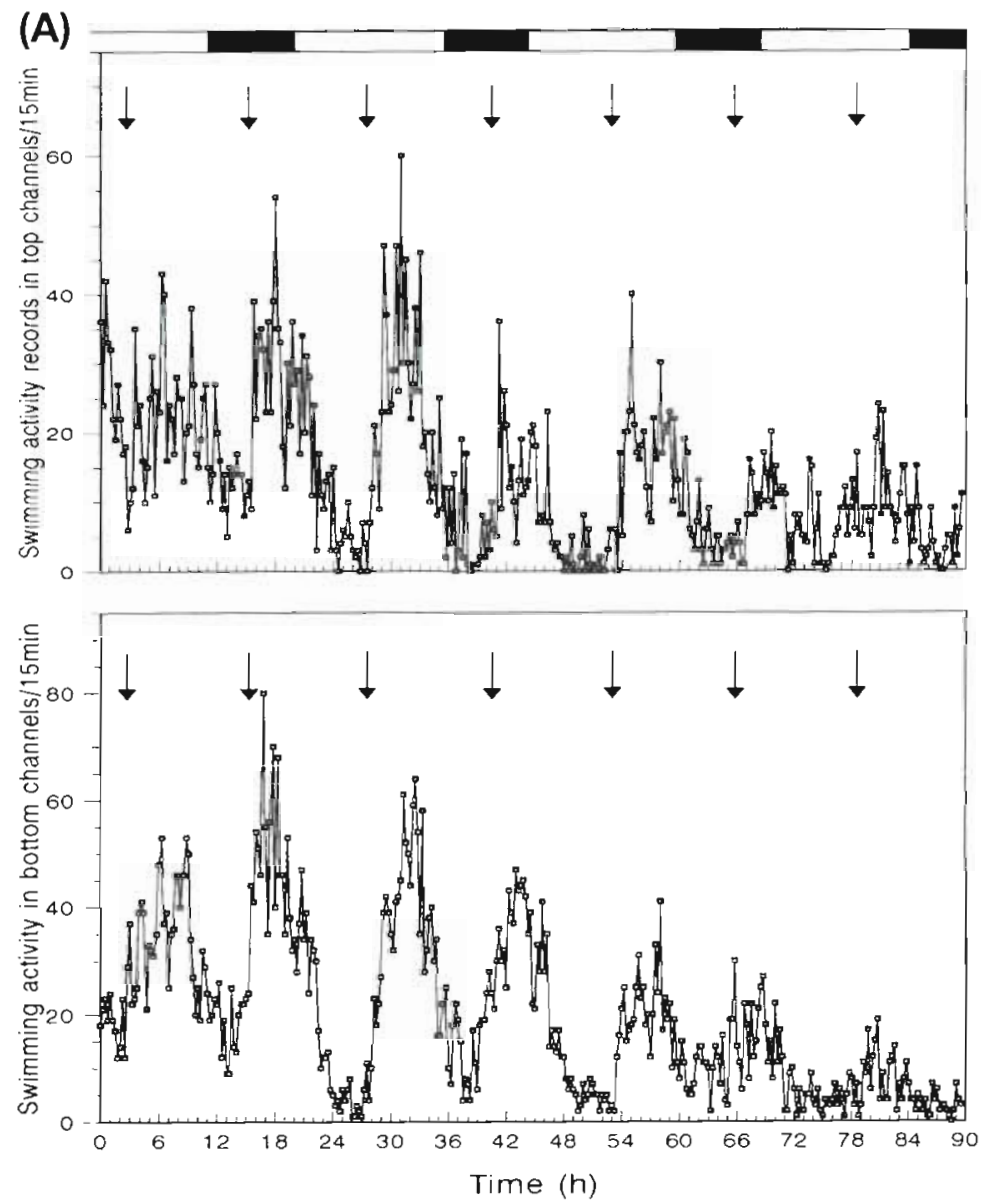

Fig. 5. Carcinus maenas. (A) Swimming activity records of field-caught megalopa larvae showing circatidal rhythms of swimming in constant laboratory conditions. Expenment started at 08:00 h, 9 August 1994 with an initial number of 260 treshly collected megalopa larvae, collected from Site 1 during nocturnal flood tide at spring tide. When the experiment stopped, 65 megalopae, 123 first stage crabs had survived. (B) Periodogram analysis of the data presented in (A). Symbols and further details as in Fig. 3

(B)
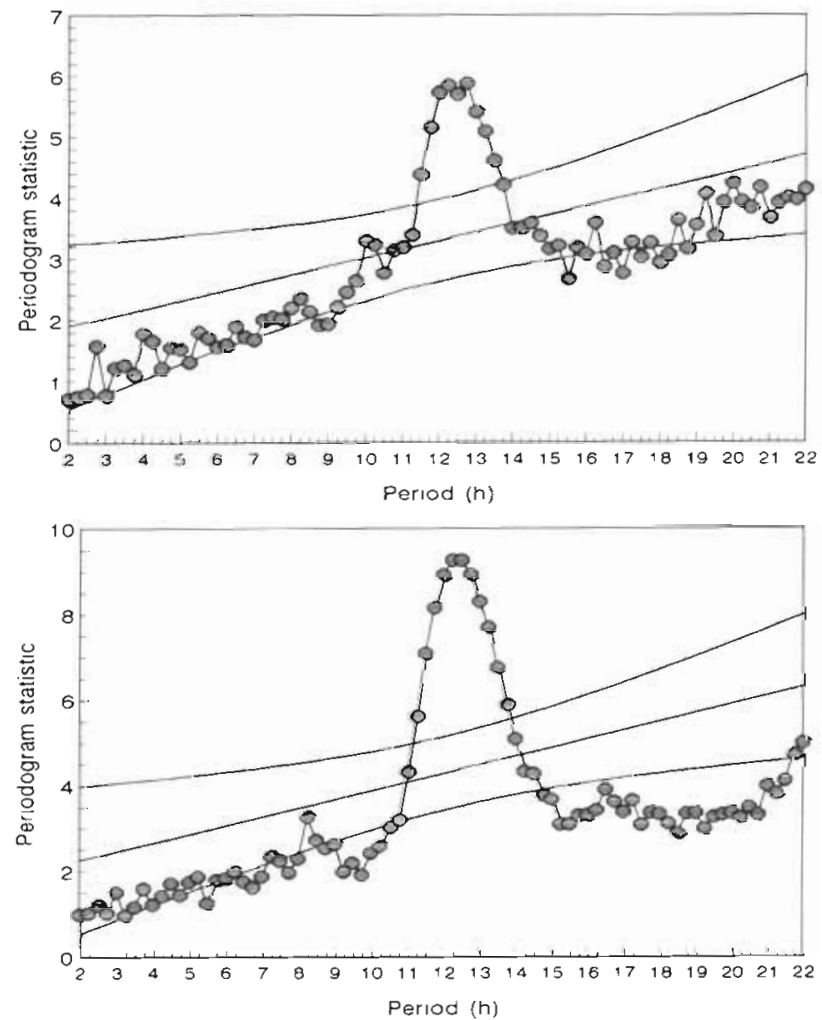

upward during the active phase, as was confirmed by intermittent observations using dim red light during the course of the experiments. Such behaviour may be a characteristic feature of late megalopae of crabs, as suggested also for species which exhibit rhythmic flood-phased swimming to achieve upstream migration in estuaries (Olmi 1994, Queiroga et al. 1994). Possibly therefore flood-tide upward swimming by $C$. maenas megalopae in the present study is initiated by exogenous responses to factors such as increasing hydrostatic pressure which is known to induce swimming in these larvae (Knight-Jones \& Qasim 1967). Discrepancies between the phasing of rhythmic swimming in the field and in the laboratory have also been reported in megalopae of the estuarine crab Uca spp., for which it has been suggested that exogenous factors, such as light, may override or suppress the expression of an endogenous tidal rhythm in the field (Tankersley \& Forward 1994, Tankersley et al. 1995). Day/night light cycles also appear to influence upward swimming of C. maenas megalopae in the sea in the present study. However, if flood-tide upward swimming by returning megalopae of $C$. maenas is driven exogenously and if the ebb-phase of the endogenous rhythms of upward swimming is not a laboratory arti- 


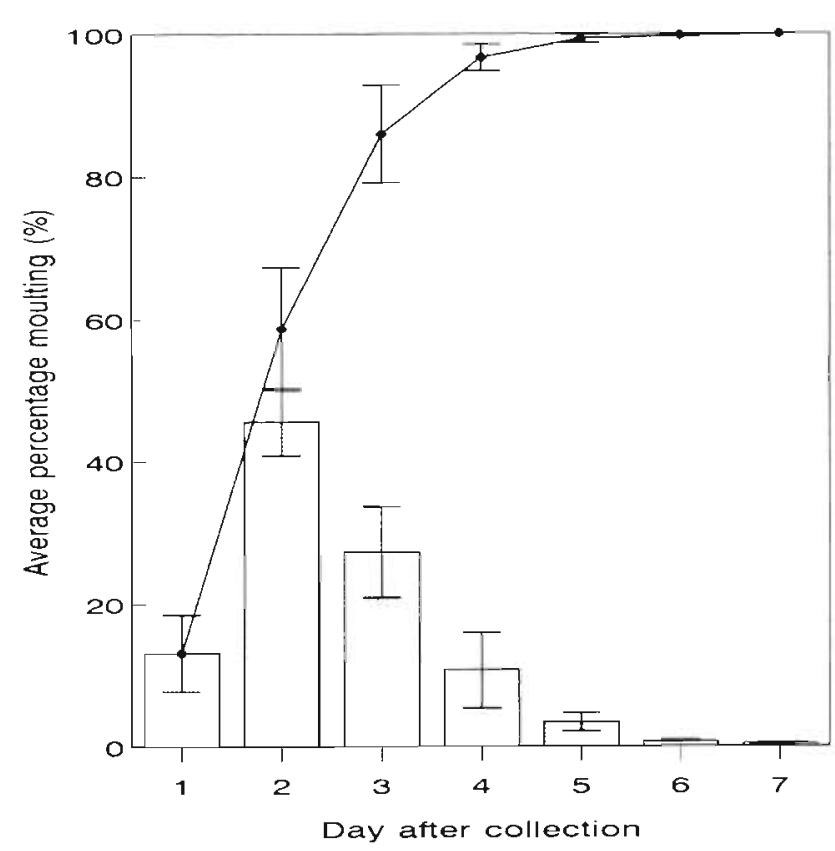

Fig. 6. Carcinus maenas. Average daily and cumulative percentage moulting of freshly collected megalopae from coastal waters in the laboratory. Bar: average daily percentage moulting. Line: average cumulative percentage moulting. Error bars indicate SD. Data were pooled from 5 sets of trials conducted during July-August 1994, involving nearly 2000 megalopae collected from Sites 1 and 2 . All trials were conducted at constant water temperatures of 16.5 or $18^{\circ} \mathrm{C}$, under natural light/dark cycle or constant light. Survival rates to first crab stage were normally more than $90 \%$

fact, then an adaptive explanation for the phase of the endogenous rhythm must be sought.

Notwithstanding the advantages of flood-tide swimming in bringing Carcinus maenas megalopae inshore, such swimming would also put them at considerable risk of premature stranding intertidally if metamorphosis was not imminent. In contrast to open coastal waters, in the surf zone megalopae of $C$. maenas were found to be abundant in the water column also during ebbing tides (Colman \& Segrove 1955). Persistent swimming during the ebb tide under endogenous control would have a strong selective advantage in preventing premature stranding of megalopae, as has been proposed for the amphipod Corophium volutator (Morgan 1965), the brown shrimp Crangon crangon (Al-Adhub \& Naylor 1975), the isopod Eurydice pulchra (Alheit \& Naylor 1976) and the mysid Neomysis integer (Hough \& Naylor 1992a). Thus, exogenously induced flood-tide swimming observed in the field coupled with high tide moulting to the first crab staqe (Zeng et al. in press) would ensure that late megalopae of $C$. maenas metamorphosed high up the shore in their 'preferred' zone. In contrast, megalopae not yet close to moulting to the first crab stage would rely on the ebb-phased endogenous swimming rhythms of circatidal periodicity to avoid premature stranding when close inshore. Recent studies (Zeng et al. in press) showing that megalopae collected from the water's edge are clearly further advanced in their moulting cycle (about $70 \%$ metamorphosed during next high tide after collection) compared to those collected just farther offshore (Fig 6) offer support for such an hypothesis. Oscillatory behaviour which reduces the risk of premature stranding would also increase the likelihood of settlement of newly metamorphosed juvenile $C$. maenas on their preferred substrata of mussel clumps and gravels on the shore (Thiel \& Dernedde 1994, C. Zeng \& P. A bello pers. obs.). In this context it is noteworthy that when towing a 2 -compartment net in the surf zone, $C$. maenas megalopae were found to be twice as numerous towards the surface as near the bottom (Colman \& Segrove 1955). Pertinently these authors also concluded that the distribution of $C$. maenas megalopae in surf plankton called for 'remarkable powers of swimming and of orientation on the part of these animals'.

Further studies are required of the rhythmic behaviour of early megalopae of Carcinus maenas from the open sea, particularly to establish whether or not they exhibit persistent circatidal rhythms. Such rhythms are understandably readily cued in the intertidal zone where later megalopae metamorphose, but the entrainment of any circatidal rhythms in early megalopae offshore would require elucidation. The recent discovery of semitidal rise and fall of the tidal turbulence field (Simpson et al. unpubl.) would provide one route for study, particularly since turbulence has been shown to entrain circatidal swimming rhythms in newly released zoea larvae of the crab (Zeng \& Naylor 1994, in press b), as well as in the intertidal isopods Excirolana chiltoni (Enright 1965) and Eurydice pulchra (Jones \& Naylor 1970, Reid \& Naylor 1986).

Acknowledgements. We thank Dr A. E. Hill for helpful discussion and Dr A. Aagaard for graciously providing the periodogram analysis computer program. Mr G. P. Jones helped in field sampling. This work was carried out during a TC fellowship to C.Z. and the research formed a part of his doctoral dissertation.

\section{LITERATURE CITED}

Al-Adhub AHY, Naylor E (1975) Emergence rhythms and tidal migrations in the brown shrimp Crangon crangon (L.). J Mar Biol Ass UK 55:801-810

Alheit J, Naylor E (1976) Behavioural basis of intertıdal zonation in Euryaice pulchra (Leach). J Exp Mar Biol Ecol 23: $135-144$

Arnold GP, Cook P (1984) Fish migration by selective tidal stream transport: first results with a computer simulation. 
model for the European continental shelf. In: McCleave JD (ed) Mechanisms of migration in fishes. Plenum Press, New York, p 227-261

Berril M (1982) The life cycle of the green crab Carcinus maenas at the northern end of its range. J Crust Biol 2:31-39

Boehlert GW, Mundy BC (1988) Roles of behavioural and physical factors in larval and juvenile fish recruitment to nursery areas. Am Fish Soc Symp 3:51-67

Boicourt WC (1982) Estuarine larval retention mechanisms on two scales. In: Kennedy $V$ (ed) Estuarine comparisons. Academic Press, New York, p 445-457

Boicourt WC (1987) Recruitment dependence on planktonic transport in coastal waters. In: Rothschild BJ (ed) Toward a theory on biological-physical interactions in the world ocean. NATO ASI Series. Series C, No. 239. Kluwer Academic Publisher, Dordrecht, p 183-202

Brookins KG, Epifanio CE (1985) Abundance of brachyuran larvae in a small coastal inlet over six consecutive tidal cycles. Estuaries 8:60-67

Castongnag M, Gilbert D (1995) Effects of tidal streams on migrating Atlantic mackerel, Scomber scomber L. ICES J Mar Sci 52:941-945

Cobb IS, Wang D, Campbell DB, Rooney P (1989) Speed and direction of swimming by postlarvae of the American lobster. Trans Am Fish Soc 118:82-86

Colman JS, Segrove F (1955) Tidal plankton over Stoupe Beck Sands, Robin Hood's Bay, Yorkshire. J Anim Ecol 24: $445-462$

Crothers JH (1968) The biology of the shore crab Carcinus maenas. 2. The life of the adult crab. Fld Stud 2:579-614

Dawirs RR (1985) Temperature and larval development of Carcinus maenas (Decapoda) in the laboratory: predictions of larval dynamics in the sea. Mar Ecol Prog Ser 24: 297-302

De Vnes MC, Tankersley RA, Forward RB Jr, Kirby-Smith WW, Luettich RA. Jr (1994) Abundance of estuarine crab larvae is associated with tidal hydrologic variables. Mar Biol 118:403-413

de Wolf $\mathrm{P}$ (1974) On the retention of marine larvae in estuaries. Thalassia Jugosl 10:415-424

Dittel AI, Epifanio CE (1990) Seasonal and tidal abundance of crab larvae in a tropical mangrove system, Gulf of Nicoya, Costa Rica. Mar Ecol Prog Ser 65:25-34

Enright JT (1965) Entrainment of a tidal rhythm. Science $147: 864-867$

Epifanio CE (1988a) Transport of invertebrate larvae between estuaries and the continental shelf. Am Fish Soc Symp 3: $104-114$

Epifanio CE (1988b) Transport of crab larvae between estuaries and the continental shelf. In: Jansson BO (ed) Lecture notes on coastal and estuarine studies, Vol 22. SpringerVerlag, Berlin. p 291-305

Epifanio CE, Valenti CC. Pembroke AE (1984) Dispersal and recruitment of blue crab larvae in Delaware Bay, USA. Estuar Coast Shelf Sci 18:1-12

Harden Jones FR, Greer Walker M, Arnold GP (1978) Tactics of fish movement strategy and water circulation. In: Charnock H, Deacon G (eds) Advances in oceanography. Plenum Press, New York, p 185-207

Hill AE (1991a) A mechanism for horizontal zooplankton transport by vertical migration in tidal currents. Mar Biol 111:485-492

Hill AE (1991b) Vertical migration in tidal currents. Mar Ecol Prog Ser 75:39-54

Hill AE (1995) The kinematical principles governing horizontal transport induced by vertical migration in tidal flows. J Mar Biol Ass UK 75:3-13
Hobbs RC, Botsford LW, Thomas A (1992) Influence of hydrographic conditions and wind forcing on the distribution and abundance of Dungeness crab, Cancer magister, larvae. Can J Fish Aquat Sci 49:1379-1388

Hough AR, Naylor E (1992a) Distribution and position maintenance behaviour of the estuarine mysid Neomysis znteger. J Mar Biol Ass UK 72:869-876

Hough AR, Naylor E (1992b) Endogenous rhythms of circatidal swimming activity in the estuarine copepod Eurytemora affints (Poppe). J Exp Mar Biol Ecol 161:27-32

Hunter E, Naylor E (1993) Intertidal migration by the shore crab Carcinus maenas. Mar Ecol Prog Ser 101:131-138

Johnson DF (1985) The distribution of brachyuran crustacean megalopae in the waters of the York River, low Chesapeake Bay and adjacent shelf: implications for recruitment. Estuar Coast Shelf Sci 20:693-705

Johnson DF, Botsford LW, Methot RD Jr, Wainwright TC (1986) Wind stress and cycles in Dungeness crab (Cancer magisterj catch off California, Oregon, and Washington. Can J Fish Aquat Sci 43:838-845

Jones DA, Naylor E (1970) The swimming rhythm of the sand beach isopod Eurydice pulchra. J Exp Mar Biol Ecol 4:188-199

Knight-Jones EW, Qasim SZ (1967) Responses of Crustacea to changes in hydrostatic pressure. Proc Symp Crust Mar Biol Ass India 3:1132-1150

Little KT, Epifanio CE (1991) Mechanisms for the reinvasion of an estuary by two species of brachyuran megalopae. Mar Ecol Prog Ser 68:235-242

McConaugha JR (1988) Export and reinvasion of larvae as regulators of estuarine decapod populations. Am Fish Soc Symp 3:90-103

Mense DJ, Wenner EL (1989) Distribution and abundance of early life history stages of the blue crab Callinectes sapidus, in tidal. marsh creeks near Charleston, South Carolina. Estuaries 12:157-168

Metcalfe JD, Arnold GP, Holford BH, Buckley A.A (1994) Migration and orientation of plaice (Pleuronectes platessa) in the southern North Sea. J Mar Biol Ass UK 74:717

Morgan E (1965) The activity rhythm of the Amphipod Corophium volutator (Pallas) and its possible relationship to changes in hydrostatic pressure associated with the tides. J Anim Ecol 34:731-746

OImi EJ III (1994) Vertical migration of blue crab Callinectes sapidus megalopae: implications for transport in estuarine. Mar Ecol Prog Ser 113:39-54

Philips BF (1981) The circulation of the southeastern Indian Ocean and the planktonic life of the western rock lobster. Aust Mar Biol A Rev 19:11-39

Queiroga H, Costlow JD. Moreira MH (1994) Larval abundance patterns of Carcinus maenas (Decapoda, Brachyura) in Canal de Mira (Ria de Avelro, Portugal). Mar Ecol Prog Ser 111:63-72

Reid DG, Naylor E (1986) An entrainment model for semilunar rhythmic swimming behaviour in the manne isopod Eurydice pulchra Leach. J Exp Mar Biol Ecol 100:25-35

Rice AL, Ingle RW (1975) The larval development of Carcinus maenas (L.) and C. mediterraneus Czerniavsky (Crustacea, Brachyura, Portunidael reared in the laboratory. Bull Br Mus (Nat Hist), Zool 28:103-119

Rijnsdorp AD, Stralen M van, Veer HW van der (1985) Selective tidal transport of North Sea plaice larvae Pleuronectes platessa in coastal nursery areas. Trans Am Fish Soc 114: $461-470$

Rothlisberg PC (1982) Vertical migration and its effect on dispersal of penaeid shrimp larvae in the Gulf of Carpentaria, Australia. Fish Bull US 80:541-554 
Rothlisberg PC (1988) Larval transport in coastal crustacean: three case histories. In: Jansson $\mathrm{BO}$ (ed) Lecture notes on coastal and estuarine studies, Vol 22. Springer-Verlag, Berlin, p 273-290

Rothlisberg PC, Church JA, Fandry CB (1995) A mechanism for near-shore concentration and estuarine recruitment of post-larval Penaeus plebejus Hess (Decapoda, Penaeidae). Estuar Coast Shelf Sci 40:115-138

Scheltema RS (1986) On dispersal and planktonic larvae of benthic invertebrates: an eclectic overview and summary of problems. Bull Mar Sci 39:209-322

Shanks AL (1983) Surface slicks associated with tidally forced interval waves may transport pelagic larvae of benthic invertebrates and fishes shoreward. Mar Ecol Prog Ser 13:31-35

Shanks AL (1985) Behavioral basis of internal-wave-induced shoreward transport of megalopae of the crab Pachygrapsus crassipes. Mar Ecol Prog Ser 24:289-295

Shanks AL (1988) Further support for the hypothesis that internal waves can cause shoreward transport of larval invertebrates and fish. Fish Bull US 86:703-714

Sherwin TJ (1992) Tidal currents in the Menai Strait. Pract Boat Owner 305:101-103

Stancyk SE, Feller RJ (1986) Transport of non-decapod invertebrate larvae in estuaries: an overview. Bull Mar Sci 39: $257-268$

Strathmann RR (1982) Selection for retention or export of larvae in estuaries. In: Kennedy $V$ (ed) Estuarine comparisons. Academic Press, New York, p 521-536

Tankersley RA, Forward RB Jr (1994) Endogenous swimming rhythms in two estuarine crab megalopae: implications for flood tide transport. Mar Biol 118:415. 423

This article was submitted to the editor
Tankersley RA, McKelvey L, Forward RB Jr (1995) Responses of estuarine crab megalopae to pressure, salinity and light: implications for flood-tide transport. Mar Biol 122:391-400

Thiel M, Dernedde T (1994) Recruitment of shore crabs Carcinus maenas on tidal flats: mussel clumps as an important refuge for juveniles. Helgoländer Meeresunters 48 : 321-332

Warman CG, Reid DG, Naylor E (1993) Variation in the tidal migratory behaviour and rhythmic light responsiveness in the shore crab, Carcinus maenas. J Mar Biol Ass UK 73:355-364

Williams JA, Naylor E (1978) A procedure for the assessment of significance of rhythmicity in time-series data. Int $\mathrm{J}$ Chronobiol 5:435-444

Wippelhauser GS, McCleave JD (1988) Rhythmic activity of migrating juvenile American eels Anguilla rostrata. J Mar Biol Ass UK 68:81-91

Zeng C. Naylor E (1994) Endogenous tidal rhythm of vertical migration in newly hatched larvae of Carcinus maenas. J Mar Biol Ass UK 74:724

Zeng C, Naylor E (1996) Endogenous tidal rhythms of vertical migration in field collected zoeae-1 larvae of the shore crab Carcinus maenas: implications for ebb tide offshore dispersal. Mar Ecol Prog Ser 132:71-82

Zeng C, Naylor E (in press a) Synchronization of endogenous tidal vertical migration rhythms in laboratory-hatched larvae of the crab Carcinus maenas. J Exp Mar Biol Ecol

Zeng C, Naylor E (in press b) Heritability of circatidal vertical migration rhythms in zoea larvae of the crab Carcinus maenas. J Exp Mar Biol Ecol

Zeng C. Naylor E, Abello P (in press) Endogenous control of timing of metamorphosis in megalopae of the shore $c r a b$ Carcinus maenas. Mar Biol

Manuscript first received: November 2, 1995

Revised version accepted: January 23, 1996 